\title{
HUBUNGAN ANTARA INTENSITAS KEBISINGAN DAN KARAKTERISTIK INDIVIDU DENGAN GANGGUAN PENDENGARAN PADA PEKERJA DI MADIUN
}

\author{
Rakhmanisa Lindhi Hanifa ${ }^{1}$, Tjipto Suwandi ${ }^{2}$ \\ ${ }^{1}$ Program Studi S1 Kesehatan Masyarakat, Fakultas Kesehatan Masyarakat, Universitas Airlangga \\ ${ }^{2}$ Departemen Keselamatan dan Kesehatan Kerja, Fakultas Kesehatan Masyarakat, Universitas Airlangga \\ rakhmanisalindhihanifa@yahoo.co.id
}

\begin{abstract}
Noise can cause different responses to one worker to another. The health effect of noise can affect to auditory. PT. INKA is an industry which run in railways by making and maintaining train, thus in its process there is possibility of noise risk. Moreover, audiometry test has not been held here. This research was established to find out the correlation between intensity of noise with hearing loss in worker. The objectives was accomplished using case control design with quantitative approach. Interviews were executed to the head of Occupational Safety and Health, 15 workers in welding 1 and 15 workers in office. Interviews were achieved to gain information about variables. The variables were divided into independent and dependent variables. The independent variables were the intensity of noise, age, years of work and the habit of using earplug. Furthermore the dependent variable was hearing loss in worker. The intensity of noise in welding 1 work area exceeds the NAB (94.8 dBA) while in office work is 63,2 dBA. The amount of hearing loss in workers for the exposed group is 4 respondents $(26,7 \%)$ and for the unexposed group is 7 respondents $(46,7 \%)$. The statistical analysis showed that there was no correlation between the intensity of noise with hearing loss which occurs in workers. The conclusion is hearing loss in worker has not necessarily caused by high intensity in work area but by another factors.
\end{abstract}

Keywords: noise intensity, hearing loss, PT.INKA Madiun

\begin{abstract}
ABSTRAK
Kebisingan dapat menimbulkan respon yang berbeda terhadap tenaga kerja satu dengan yang lainnya. Pengaruh dari adanya kebisingan kepada kesehatan yaitu terjadinya kerusakan pada indera pendengar. PT.INKA merupakan industri dalam bidang perkeretaapian dengan kegiatan pembuatan dan perawatan kereta yang memungkinkan adanya resiko kebisingan, selain itu PT.INKA juga belum mengadakan pemeriksaan tes audiometri pada pekerjanya. Penelitian ini dilakukan untuk mengetahui hubungan antara intensitas kebisingan dengan gangguan pendengaran pada pekerja di PT INKA. Penelitian dilaksanakan dengan rancangan case control dengan melakukan pendekatan kuantitatif. Wawancara dilakukan pada kepala bagian K3, 15 pekerja pada welding 1 dan 15 pekerja pada kantor. Wawancara dilakukan untuk mendapat informasi mengenai variabel yang diteliti. Selain itu dilakukan observasi mengenai kebiasaan pekerja dalam pemakaian APT. Variabel bebas penelitian adalah intensitas kebisingan, usia, masa kerja dan kebiasaan memakai APT. Sedangkan variabel terikat adalah gangguan pendengaran pada pekerja. Kebisingan pada area kerja welding 1 melebihi NAB (94,8 dBA) sedangkan pada ruang kantor sebesar 63,2 dBA. Gangguan pendengaran yang terjadi pada pekerja di PT.INKA untuk kelompok terpapar yang bekerja pada bagian welding 1 sebanyak 4 responden $(26,7 \%)$ dan untuk kelompok tidak terpapar yaitu pekerja pada bagian kantor sebanyak 7 responden (46,7\%). Hasil uji analisis statistik menunjukkan bahwa tidak ada hubungan antara intensitas kebisingan dengan gangguan pendengaran yang terjadi pada pekerja di PT.INKA. Kesimpulan yang dapat ditarik adalah gangguan pendengaran yang terjadi pada pekerja belum tentu disebabkan oleh intensitas yang tinggi pada area kerja melainkan ada beberapa faktor lain yang dapat menyebabkan gangguan pendengaran tersebut.
\end{abstract}

Kata Kunci: intensitas kebisingan, gangguan pendengaran, PT.INKA Madiun 
Rakhmanisa, et al. Hubungan Antara Intensitas Kebisingan dan Karakteristik Individu Dengan Gangguan Pendengaran Pada Pekerja di Madiun
JPH RECODE Maret 2018; 1 (2) : 144-154 http://e-journal.unair.ac.id/JPHRECODE

\section{PENDAHULUAN}

Sektor industri sebagai salah satu bagian yang terpenting dalam pembangunan, melibatkan berbagai mesin dan peralatan yang digunakan untuk melakukan sistem produksi industri. Mesin dan peralatan tersebut di satu sisi penting bagi pembangunan, namun di sisi lain juga dapat mengakibatkan dampak yang negatif bagi kesehatan manusia. Hal ini disebabkan industri melibatkan manusia, alat dan lingkungan kerja merupakan sebuah sistem yang saling berhubungan (Siswanto, 1991).

Berdasarkan Peraturan Menteri Tenaga Kerja RI No. 13/Men/X/2011 Kebisingan adalah suara yang tidak dikehendaki atau bersifat mengganggu (Menteri Tenaga Kerja dan Transmigrasi, 2011). Kebisingan dapat menimbulkan respon yang berbeda terhadap tenaga kerja satu dengan yang lainnya. Di Indonesia, Nilai Ambang Batas untuk kebisingan adalah sebesar $85 \mathrm{dBA}$ dan lama pemajanan tidak boleh melebihi 8 jam perhari atau 40 jam dalam seminggu. Bila ketentuan ini dilanggar, maka akan menimbulkan gangguan pendengaran bagi tenaga kerja yang terpapar.

Di Indonesia sebagian besar industri menggunakan mesin dan peralatan bagi proses produksinya. Penggunaan mesin dan peralatan tersebut dapat memberikan dampak positif selain itu juga dapat memberikan pengaruh buruk terutama apabila tidak dikelola dengan baik. Salah satu dampak negatif dari penggunaan mesin dan peralatan tersebut adalah dapat menjadi sumber kebisingan bagi pekerja. Dalam hal ini, tenaga kerjalah yang langsung berhadapan dengan kebisingan tersebut.

Kebisingan dapat menyebabkan kehilangan pendengaran, kejengkelan dan merusak beberapa pekerjaan. Kehilangan pendengaran pada mulanya mungkin bersifat sementara atau dapat juga bersifat tetap tergantung pada lama dan paparan yang didapat.

Kehilangan pendengaran yang bersifat sementara dapat juga dikatakan kelelahan pendengaran, dimana kerusakan tersebut dapat dipulihkan beberapa waktu bila berada pada tempat yang jauh dari kebisingan. Hal demikian dapat terjadi bila dalam beberapa menit terpapar oleh kebisingan yang kuat. Dengan lamanya paparan (bulan atau tahun) terhadap kebisingan kemungkinan pemulihan pendengaran hanya dapat dilakukan sebagian atau dapat menjadi gangguan pendengaran yang tetap.
Bahaya utama yang berdampak dari suara bising yang berlebihan adalah kehilangan pendengaran. Ketika seseorang terpapar kebisingan dalam waktu yang cukup lama maka akan merusak telinga bagian dalam sehingga kemampuan untuk mendengar suara berfrekuensi tinggi menjadi hilang. Terlebih lagi, apabila hal ini semakin parah maka suara berfrekuensi rendah juga tidak dapat didengar. Selain itu, kebisingan juga mempengaruhi tekanan darah seseorang, sesuai dengan penelitian yang dilakukan oleh Albustomi dan Denny (2017) menunjukkan bahwa terdapat perbedaan tekanan darah sebelum dan setelah bekerja pada pekerja yang terpapar bising di PT $\mathrm{X}$.

Menurut penelitian Ali (2006) Berdasarkan Data survei Multi Center Study di Asia Tenggara, prevalensi ketulian yang terjadi di Indonesia cukup tinggi yaitu 4,6\%, sedangkan 3 negara lainnya yakni Sri Lanka (8,8\%), Myanmar $(8,4 \%)$ dan India 6,3\%). Walaupun bukan yang tertinggi tetapi prevalensi $4,6 \%$ tergolong cukup tinggi, sehingga dapat menimbulkan masalah sosial di tengah masyarakat.

Berdasarkan hasil Riskesdas Indonesia tahun 2013 prevalensi gangguan pendengaran secara nasional sebesar 2,6 persen. Sedangkan prevalensi gangguan pendengaran untuk wilayah Jawa Timur sebesar 2,9 persen.

Dalam melakukan tugasnya diperusahaan seseorang atau sekelompok pekerja beresiko mendapatkan kecelakaan ataupun penyakit akibat kerja. Memperkecil kecelakaan dan penyakit akibat kerja bukan saja menekan biaya tetapi juga menghindari inefisiensi dan kerugian. Kecelakaan tersebut dapat memperlambat produksi, mengganggu ketepatan waktu produksi dan kerugian hilangnya modal atau alat produksi. Gangguan tersebut akan mengurangi kepercayaan pelanggan dan sebaliknya ketepatan waktu akan meningkatkan kepercayaan pelanggan. Kerugian akibat kecelakaan dan penyakit akibat kerja mungkin saja kecil, tetapi bila dihitung kehilangan keuntungan potensial akibat terjadinya kecelakaan atau sakit adalah sangat besar, termasuk dapat menurunkan citra perusahaan (Darmanto, 1999).

Gangguan pendengaran adalah suatu penyakit berkurangnya atau hilangnya fungsi 
Rakhmanisa, et al. Hubungan Antara Intensitas Kebisingan dan Karakteristik Individu Dengan Gangguan Pendengaran Pada Pekerja di Madiun

pendengaran di salah satu atau kedua telinga, timbul secara mendadak ataupun perlahan.

Telinga adalah bagian yang didesain secara cerdas yang mengubah geombang bunyi mekanis di udara menjadi denyut-denyut elektris pada syaraf pendengaran. Telinga terdiri dari tiga bagian yaitu: telinga luar, telinga tengah, dan telinga dalam. Suara yang keras dapat menyebabkan otot pada telinga untuk menarik sisi-sisi ossicle dan mengurangi intensitas suara yang mencapai telinga dalam.

Berdasarkan hasil penelitian yang dilakukan oleh Rafika Adila, 2012 mengenai pengaruh kebisingan terhadap nilai ambang dengar, dari 40 responden yang terpapar bising, rata-rata nilai ambang dengar telinga kiri yaitu 27,78 dBA dan memiliki nilai minimum dan maksimum sebesar 16 dan 45 dBA. Dan untuk telinga kanan memiliki nilai ambang dengar rata-rata $27,70 \mathrm{dBA}$ dengan nilai minimum dan maksimum sebesar $16 \mathrm{dBA}$ dan $43 \mathrm{dBA}$. Hal tersebut menunjukkan nilai ambang dengar telinga kiri dan responden mengalami gangguan pendengaran

Penelitian Jayanti (2015) mengenai hubungan intensitas kebisingan dengan nilai ambang dengar di PT.X menunjukkan bahwa adanya hubungan antara kebisingan dengan nilai ambang dengar telinga kanan dan kiri pada tenaga kerja di lantai 3 PT.X. Dimana terdapat 24 responden $(66,7 \%)$ yang mengalami gangguan pendengaran dari jumlah 36 responden pada kelompok terpapar.

PT. INKA (Persero) merupakan Badan Usaha Milik Negara Industri Strategis yang bergerak dalam bidang manufaktur dan jasa perkeretaapian, dimana dalam kegiatannya memungkinkan penggunakan mesin maupun alat yang mengeluarkan suara bising dan alat-alat tersebut kemungkinan memiliki intensitas kebisingan melebihi Nilai Ambang Batas (NAB). Pengoperasian mesin dan alat dalam jangka waktu yang lama sangat mungkin menimbulkan gangguan pendengaran bagi pekerja akibat adanya paparan kebisingan. Selain itu PT.INKA juga belum pernah mengadakan pemeriksaan audiometri kepada para pekerjanya.

Berdasarkan uraian diatas, maka penulis tertarik untuk mengadakan penelitian tentang Hubungan antara Intensitas Kebisingan dan Karakteristik Individu dengan Gangguan
JPH RECODE Maret 2018; 1 (2) : 144-154 http://e-journal.unair.ac.id/JPHRECODE

Pendengaran Pada Pekerja di PT.INKA Madiun Tahun 2015

\section{METODE}

Penelitian ini menggunakan metode kuantitatif dengan jenis penelitian observasional analitik dan menurut waktu, dilakukan rancangan penelitian case control. Penelitian ini dilaksanakan di PT.INKA Madiun pada bulan Oktober-Desember 2015.

Pengukuran dilakukan pada dua variabel yaitu variabel independen dan variabel dependen. Variabel independen yang diukur adalah intensitas kebisingan dan karakteristik pekerja pada unit welding 1 yang terpapar bising di PT INKA. Output dari pengukuran ini adalah diketahuinya gambaran intensitas kebisingan dan gambaran karakteristik pekerja. Sedangkan variabel dependen berupa hasil pemeriksaan gangguan pendengaran pada pekerja. Outputnya adalah diketahuinya kejadian gangguan pendengaran pada pekerja.

Populasi kasus merupakan semua pekerja yang bekerja pada area kerja welding 1 sebanyak 25 orang, sampel yang diambil sebanyak 15 orang dari populasi pekerja pada welding 1 yang sesuai dengan kriteria : Usia tidak lebih dari 40 tahun, tidak dalam kondisi sakit, tidak sedang mengkonsumsi obat-obatan yang dapat mempengaruhi pendengaran dalam jangka waktu yang lama, belum pernah bekerja di tempat bising yang lain, tidak memiliki riwayat penyakit telinga. Sedangkan untuk populasi kontrol diambil 15 orang dari bagian kantor.

Untuk pengumpulan data dalam penelitian ini yaitu data primer yang diperoleh melalui wawancara dengan menggunakan kuesioner dan lembar wawancara, observasi menggunakan lembar observasi, melakukan pengukuran kebisingan dengan menggunakan alat sound level meter dengan skala A. Sound level meter dilengkapi dengan mikrofon yang mendekati suara, mengkonversikannya ke dalam signal listrik dan memperbesar signal sampai pada tingkat tekanan suara. Bising di dalam bangunan datang dari berbagai arah karena suara yang berasal dari mesin dan peralatan yang sedang berjalan dan digunakan kemudian dipantulkan melalui dinding langit-langit dan lantai. Alat ini dapat mengukur kebisingan antara 30-130 dB dan frekuensi 20-20.000 Hz. Keras dan intensitas kebisingan dinyatakan dalam desibel (dB). Sedangkan untuk mengetahui kondisi 
Rakhmanisa, et al. Hubungan Antara Intensitas Kebisingan dan Karakteristik Individu Dengan Gangguan Pendengaran Pada Pekerja di Madiun

pendengaran pekerja dilakukan pengukuran audiometri dengan menggunakan alat audiometer Oscilla SM950 dengan bantuan pihak ketiga yaitu Unit Pelaksana Teknis Keselamatan dan Kesehatan Kerja (UPT K3) Surabaya.

Analisis univariat merupakan variabel bebas yang disajikan dalam bentuk tabel distribusi frekuensi. Analisis bivariat dilakukan untuk menguji hubungan antara karakteristik individu dengan gangguan pendengaran pada pekerja dengan mengggunakan uji statistik korelasi pearson dan spearman, sedangkan intensitas kebisingan dengan gangguan pendengaran pada pekerja, menggunakan ChiSquare test pada CI $95 \%$ dan $\alpha=0,05$ dengan bantuan program SPSS.

\section{HASIL}

PT. Industri Kereta Api (INKA) Madiun merupakan Badan Usaha Milik Negara Industri Strategis (BUMN-IS) yang bergerak dalam bidang manufaktur dan jasa perkeretaapian yang berada di desa Madiun Lor Kecamatan Mangunharjo Kotamadya Madiun dengan lokasi di Jalan Yos Sudarso 71 Madiun. Kegiatan utama PT.INKA antara lain yaitu pembuatan kereta api (gerbong barang, gerbong ballast, gerbong batubara, gerbong tanki, kereta penumpang, kereta rel diesel, kereta rel listrik),

Tabel 1. Distribusi Usia Kelompok Terpapar dan Tidak Terpapar Pada Pekerja di PT.INKA Madiun Tahun 2015

\begin{tabular}{|c|c|c|c|c|c|}
\hline \multirow{2}{*}{ No. } & \multirow{2}{*}{$\begin{array}{c}\text { Usia Pekerja } \\
\text { (tahun) }\end{array}$} & \multicolumn{2}{c|}{ Terpapar } & \multicolumn{2}{c|}{ Tidak Terpapar } \\
\cline { 3 - 6 } & & $\mathbf{N}$ & $\mathbf{\%}$ & $\mathbf{N}$ & $\mathbf{\%}$ \\
\hline 1. & $\leq 30$ tahun & 10 & 66,7 & 10 & 66,7 \\
2. & $>30$ tahun & 5 & 33,3 & 5 & 33,3 \\
\hline \multicolumn{2}{|r|}{ Jumlah } & 15 & 100 & 15 & 100 \\
\hline
\end{tabular}

Usia pekerja pada kelompok terpapar dan tidak terpapar sebagian besar memiliki usia $\leq 30$ jasa perawatan besar perkeretaapian, perdagangan lokal,impor dan ekspor barang dan jasa yang berhubungan dengan perkeretaapian, jasa konsultasi dan rekayasa bidang perkeretaapian, pembuatan barang-barang dalam rangka program diversifikasi produk antara lain : aerobridge/boarding car, grandby car, container office, track motor car, airport trolley, automotive product dan toilet module dan pelayanan purna jual perkeretaapian. Area PPL welding 1 memiliki berbagai macam jenis pekerjaan antara lain welding, grinding, reforming, drilling, laser cutting, sawing, punching dan bending dengan letak mesin dan alat kerja berada pada pinggir ruangan dan ditengah ruangan sebagai jalan.

Untuk area welding 1 intensitas kebisingannya sebesar 94,8 dBA. Sedangkan Ruang kantor merupakan ruang terpisah dari area welding 1 dimana ruang tersebut jauh dari kebisingan, didalam ruangan tersebut berisi alat komputer untuk menunjang pekerjaan karyawan. Didalam ruangan ini intensitas kebisingannya sebesar 63,2 dB.

Jenis kebisingan yang terjadi di area welding 1 merupakan kebisingan sesaat karena pengukuran kebisingan dilakukan pada satu waktu atau satu kali dalam sehari. Berdasarkan kriteria pekerja dapat diketahui :

${ }^{i}$ Tabel 2. Distribusi Masa Kerja Kelompok Terpapar dan Tidak Terpapar Pada Pekerja di PT.INKA Madiun Tahun 2015

\begin{tabular}{|c|c|c|c|c|c|}
\hline \multirow{2}{*}{ No. } & \multirow{2}{*}{$\begin{array}{c}\text { Masa Kerja } \\
\text { (tahun) }\end{array}$} & \multicolumn{2}{|c|}{ Terpapar } & \multicolumn{2}{|c|}{ Tidak Terpapar } \\
\hline & & $\mathbf{N}$ & $\%$ & $\mathbf{N}$ & $\%$ \\
\hline 1. & $<5$ tahun & 9 & 60 & 12 & 80 \\
\hline 2. & $\geq 5$ tahun & 6 & 40 & 3 & 20 \\
\hline & Jumlah & 15 & 100 & 15 & 100 \\
\hline
\end{tabular}


Masa kerja pada kelompok terpapar dan tidak terpapar sebagian besar memiliki masa kerja < 5 tahun yaitu sebesar $60 \%$ pada Tabel 3. Distribusi Penggunaan APT Kelompok Terpapar dan Tidak Terpapar Pada Pekerja di PT.INKA Madiun Tahun 2015

\begin{tabular}{|l|l|c|c|c|c|}
\hline \multirow{2}{*}{ No. } & \multirow{2}{*}{ Penggunaan APT } & \multicolumn{2}{c|}{ Terpapar } & \multicolumn{2}{c|}{ Tidak Terpapar } \\
\cline { 3 - 6 } & & $\mathbf{N}$ & $\mathbf{\%}$ & $\mathbf{N}$ & $\mathbf{\%}$ \\
\hline 1. & Ya, selalu & 5 & 33,3 & 0 & 0 \\
\hline 2. & Kadang-kadang & 9 & 60 & 0 & 0 \\
\hline 3. & Tidak & 1 & 6,7 & 15 & 100 \\
\hline \multicolumn{2}{|l|}{ Jumlah } & 15 & 100 & 15 & 100 \\
\hline
\end{tabular}

Kebiasaan penggunaan Alat Pelindung Telinga (APT) pada kelompok terpapar sebagian besar memiliki kebiasaan kadang-kadang menggunakan APT sebesar $60 \%$. Sedangkan pada kelompok tidak terpapar kesemuanya tidak menggunakan APT.

Tabel 4. Distribusi Nilai Ambang Dengar Telinga Kiri Kelompok Terpapar dan Tidak Terpapar Pada Pekerja di PT.INKA Madiun Tahun 2015

\begin{tabular}{|l|l|c|c|c|c|}
\hline \multirow{2}{*}{ No. } & \multirow{2}{*}{ Nilai Ambang Dengar (dBA) } & \multicolumn{2}{|c|}{ Terpapar } & \multicolumn{2}{c|}{ Tidak Terpapar } \\
\cline { 3 - 6 } & & $\mathbf{N}$ & $\mathbf{\%}$ & $\mathbf{N}$ & $\mathbf{\%}$ \\
\hline 1. & $0-25$ (Normal) & 11 & 73,3 & 11 & 73,3 \\
\hline 2. & $26-40$ (Ringan) & 2 & 13,3 & 4 & 26,7 \\
\hline 3. & $41-60$ (Sedang) & 1 & 6,7 & 0 & 0 \\
\hline 4. & $61-90$ (Berat) & 1 & 6,7 & 0 & 0 \\
\hline \multicolumn{2}{|l}{ Jumlah } & 15 & 100 & 15 & 100 \\
\hline
\end{tabular}

Sebagian besar nilai ambang dengar pekerja pada telinga kanan adalah normal sebesar 73,3\% pada kelompok terpapar dan tidak terpapar. Dan jenis gangguan pendengaran yang banyak terjadi yaitu gangguan pendengaran

Tabel 5. Distribusi Nilai Ambang Dengar Telinga Kanan Kelompok Terpapar dan Tidak Terpapar Pada Pekerja di PT.INKA Madiun Tahun 2015

\begin{tabular}{|l|l|c|c|c|c|}
\hline \multirow{2}{*}{ No. } & \multirow{2}{*}{ Nilai Ambang Dengar (dBA) } & \multicolumn{2}{|c|}{ Terpapar } & \multicolumn{2}{c|}{ Tidak Terpapar } \\
\cline { 3 - 6 } & & $\mathbf{N}$ & $\mathbf{\%}$ & $\mathbf{N}$ & $\mathbf{\%}$ \\
\hline 1. & $0-25$ (Normal) & 12 & 80 & 8 & 53,3 \\
\hline 2. & $26-40$ (Ringan) & 3 & 20 & 7 & 46,7 \\
\hline & Jumlah & 15 & 100 & 15 & 100 \\
\hline
\end{tabular}

Sebagian besar nilai ambang dengar pekerja pada telinga kanan adalah normal sebesar $80 \%$ pada kelompok terpapar dan $53,3 \%$ pada kelompok tidak terpapar. Dan jenis gangguan pendengaran yang banyak terjadi yaitu ringan pada kelompok tidak terpapar sebanyak $26,7 \%$.

Berdasarkan hasil pengukuran audiometri pada kelompok pekerja terpapar dan tidak terpapar, dapat diketahui nilai ambang dengar pekerja sebagai berikut :

kelompok terpapar dan $80 \%$ pada kelompok tidak terpapar.

$26,7 \%$. 
Dengan menggunakan tabel bivariat, dapat dilihat distribusi karakteristik individu degan gangguan pendengaran yaitu gangguan pendengaran pada telinga kiri banyak terjadi pada usia $\leq 30$ tahun (20\%) dan dengan masa kerja $<5$ tahun $(23,3 \%)$, sedangkan untuk kebiasaan penggunaan APT, gangguan pendengaran banyak terjadi pada kelompok tidak terpapar yang tidak menggunakan $\operatorname{APT}(16,6 \%)$.

Pada telinga kanan, gangguan pendengaran banyak terjadi pada usia usia $\leq 30$ tahun $(26,7 \%)$ dengan masa kerja $<5$ tahun (33,3\%), sedangkan untuk kebiasaan penggunaan APT, gangguan pendengaran lebih banyak terjadi pada kelompok tidak terpapar yang tidak menggunakan APT(26,7\%).

Berdasarkan hasil uji statistik, dapat diketahui hubungan antara karakteristik individu dengan nilai ambang dengar telinga kiri pada karakteristik usia didapat hasil sig 0,294 dimana sig $>\alpha$ yang berarti tidak terdapat hubungan antara usia dengan gangguan pendengaran yang terjadi pada pekerja.

Pada karakteristik masa kerja didapat hasil sig 0,505 , sig $>\alpha$ yang berarti tidak ada Tabel 6. Distribusi Status Gangguan Pendengaran Telinga Kiri dan kanan Kelompok Terpapar dan Tidak Terpapar Pada Pekerja di PT.INKA Madiun Tahun 2015

\begin{tabular}{|l|l|c|c|c|c|}
\hline \multirow{2}{*}{ No } & \multicolumn{1}{|c|}{$\begin{array}{c}\text { Status Gangguan } \\
\text { Pendengaran }\end{array}$} & \multicolumn{2}{c|}{ Terpapar } & \multicolumn{2}{c|}{ Tidak Terpapar } \\
\cline { 3 - 6 } & \multicolumn{1}{|c|}{$\mathbf{N}$} & $\mathbf{\%}$ & $\mathbf{N}$ & $\mathbf{\%}$ \\
\hline 1. & $\begin{array}{l}\text { Normal } \\
(\leq 25 \mathrm{dBA})\end{array}$ & 11 & 73,3 & 8 & 53,3 \\
\hline 2. & $\begin{array}{l}\text { Tidak Normal } \\
(>25 \mathrm{dBA})\end{array}$ & 4 & 26,7 & 7 & 46,7 \\
\hline \multicolumn{2}{|l}{ Jumlah } & 15 & 100 & 15 & 100 \\
\hline
\end{tabular}

Gangguan pendengaran yang terjadi banyak dialami pada pekerja yang tidak terpapar kebisingan sebesar $46,7 \%$ sedangkan pada pekerja yang terpapar sebesar $26,7 \%$.

\section{Kelemahan Penelitian}

Hasil dari penelitian menunjukkan tidak ada hubungan antara intensitas kebisingan dan karakteristik individu dengan gangguan pendengaran dikarenakan adanya kelemahan dalam penelitian, yaitu : Pengukuran intensitas kebisingan dilakukan sesaat hanya pada satu waktu yaitu pukul 10.00. Sedangkan kebisingan di area kerja pengelasan (welding) tidak stabil sehingga hasil pengukuran tidak hubungan antara masa kerja dengan gangguan pendengaran pada pekerja.

Berdasarkan pada uji korelasi spearman pada kelompok terpapar didapat hasil sig 0,977, sig $>\alpha$ yang berarti tidak ada hubungan antara kebiasaan penggunaan APT dengan gangguan pendengaran pada pekerja.

Sedangkan untuk nilai ambang dengar telinga kanan, berdasarkan hasil uji statistik, dapat diketahui hubungan usia dengan gangguan pendengaran yaitu tidak terdapat hubungan dikarenakan hasil sig 0,787 dimana sig $>\alpha$.

Pada karakteristik masa kerja didapat hasil sig 0,804 , sig $>\alpha$ yang berarti tidak ada hubungan antara masa kerja dengan gangguan pendengaran pada pekerja.

Berdasarkan pada uji korelasi spearman pada kelompok terpapar didapat hasil sig 0,796, sig $>\alpha$ yang berarti tidak ada hubungan antara kebiasaan penggunaan APT dengan gangguan pendengaran pada pekerja. Status gangguan pendengaran yang dialami pekerja adalah sebagai berikut : menggambarkan kebisingan selama 8 jam kerja, sebaiknya pengukuran dilakukan beberapa waktu dalam 1 hari. Saat akan melakukan pengukuran audiometri, pekerja yang terpapar bising tidak mendapatkan istirahat terlebih dahulu \pm 1 jam sehingga pekerja kemungkinan mendengar kebisingan saat pengukuran akibat pajanan bising dengan intensitas tinggi pada area kerjanya yang mengakibatkan responden tidak dengan benar memberikan respon saat mendengar suara pada tes audiometri sehingga data yang didapat menjadi tidak akurat. 
Rakhmanisa, et al. Hubungan Antara Intensitas Kebisingan dan Karakteristik Individu Dengan Gangguan Pendengaran Pada Pekerja di Madiun
JPH RECODE Maret 2018; 1 (2) : 144-154 http://e-journal.unair.ac.id/JPHRECODE

\section{PEMBAHASAN}

Berdasarkan hasil pengukuran kebisingan di area PPL welding 1 dan ruang kantor didapatkan hasil rata-rata kebisingan di area welding 1 sebesar 94,8 dBA dan di ruang kantor rata-rata kebisingannya sebesar 63,2 dBA. Menurut Permenaker RI No.13/Men/X/2011 tentang nilai ambang batas faktor fisika dan Kimia di tempat kerja, hasil intensitas kebisingan pada welding 1 melebihi NAB dan pada Permenaker tersebut juga menyatakan bahwa pekerja tidak boleh terpapar lebih dari 85 dBA selama 8 jam, untuk kebisingan sebesar 94,8 dBA hanya diperbolehkan terpapar 1 jam. Dan pada kenyataannya pekerja pada welding 1 terpapar kebisingan sebesar 94,8 dBA lebih dari 1 jam (Menteri Tenaga Kerja dan Transmigrasi, 2011).

Jenis kebisingan yang ada di area kerja welding 1 merupakan jenis kebisingan sesaat karena pengukuran kebisingan dilakukan pada satu waktu. Sehingga hasil kebisingan yang didapat hanya pada saat itu saja. Pengukuran di area kerja dilakukan pada waktu pagi hari pukul 10.00 WIB.

Keadaan area bising yaitu welding 1 disebabkan oleh suara-suara dari kegiatan welding, grinding, reforming, drilling, laser cutting, sawing, punching dan bending yang hanya berhenti pada saat istirahat selama 1 jam. Disinilah terjadinya paparan pada pekerja welding 1 . Berbeda dengan kelompok yang tidak terpapar, tugas mereka adalah bekerja dengan komputer atau mengurus berkas dimana tempat mereka bekerja tidak terpapar oleh kebisingan.

\section{Usia}

Usia pekerja sebagian besar memiliki usia muda yaitu $\leq 30$ tahun. Menurut uji statistik, hubungan antara usia dengan kejadian gangguan pendengaran didapatkan hasil sig > 0,05 bahwa tidak ada hubungan antara usia dengan gangguan pendengaran pada telinga kiri dan kanan. Artinya kenaikan nilai ambang dengar tidak berkaitan dengan usia pekerja, gangguan pendengaran bisa terjadi pada usia berapapun dan tidak ada kecenderungan kerentanan pada usia muda maupun tua.

Menurut Sihar (2005) usia merupakan faktor terjadinya kenaikan nilai ambang dengar seseorang, semakin bertambah usia seseorang maka akan semakin naik nilai ambang dengarnya. Menurut Pulat (1992) dan Grandjean
(1993) menyatakan bahwa ambang dengar meningkat secara progresif dengan umur. Selain itu menurut Standard (1979) menerangkan bahwa sejumlah tenaga kerja yang terpapar bising $90 \mathrm{~dB}$ maka pada usia 20-29 tahun hanya 3\% akan mengalami ketulian, 30-39 tahun naik menjadi $8 \%$ akan mengalami ketulian, 40-49 tahun sebanyak $16 \%$ akan mengalami ketulian dan diatas 50 tahun $27 \%$ akan mengalami ketulian.

Hasil dari penelitian ini tidak sesuai dengan teori yang ada karena kelompok usia yang lebih muda ( $\leq 30$ tahun) lebih banyak terjadi gangguan pendengaran. Hal ini kemungkinan disebabkan aktifitas pekerja usia muda di luar pekerjaannya seperti banyaknya mendengarkan musik terlalu lama atau sering yang dapat mempengaruhi fungsi pendengaran sehingga berakibat pada adanya kenaikan ambang dengar pada telinga kiri maupun kanan.

Berdasarkan penelitian Kusumawati (2012) mengenai hubungan tingkat kebisingan dengan gangguan pendengaran di PT. X, menunjukkan bahwa tidak ada hubungan antara usia pekerja dengan gangguan pendengaran dengan hasil 23 orang $(36,5 \%)$ mengalami gangguan pendengaran pada usia kurang dari 40 tahun.

Selain itu, pada penelitian Pratama (2010) menyatakan bahwa seiring bertambahnya usia maka sebagian dari sel-sel rambut telinga bagian dalam akan mati. Sehingga hal ini yang menyebabkan sesorang mudah untuk mengalami tuli ketika usia lanjut. Namun, apabila seseorang mendapat tekanan kebisingan dengan intensitas tinggi secara kontinyu untuk jangka waktu yang panjang, maka banyak sel - sel rambutnya menjadi mati meskipun masih berumur muda. Jadi, lamanya paparan kebisingan dapat mempengaruhi ketulian seseorang. Sel rambut berfungsi sebagai reseptor nada tinggi akan lebih dahulu mati, oleh karena itu kemunduran pendengaran pertama kali terjadi pada frekuensi 4000 - 6000 Hz. Oleh karena itu, ketika frekuensi bicara berkisar antara $500-3000 \mathrm{~Hz}$, maka Noise Induced Hearing Loss (NIHL) awal biasanya tidak disadari, bahkan oleh orang yang bersangkutan. Namun, hal ini berbeda pada seorang pemusik, ia akan menyadari gangguannya lebih dahulu, karena apresiasi musik membutuhkan kepekaan suara yang lebih tinggi daripada untuk mendengar percakapan. 
Rakhmanisa, et al. Hubungan Antara Intensitas Kebisingan dan Karakteristik Individu Dengan Gangguan Pendengaran Pada Pekerja di Madiun
JPH RECODE Maret 2018; 1 (2) : 144-154 http://e-journal.unair.ac.id/JPHRECODE

\section{Masa Kerja}

Masa kerja pekerja pada kelompok terpapar dan tidak terpapar sebagian besar memiliki masa kerja < 5 tahun. Menurut uji statistik, hubungan antara masa kerja dengan kejadian gangguan pendengaran didapatkan hasil sig > 0,05 hal tersebut menunjukkan bahwa tidak ada hubungan antara masa kerja dengan gangguan pendengaran pada telinga kiri dan kanan. Artinya lama masa kerja tidak berkaitan dengan gangguan pendengaran pada pekerja.

Berdasarkan teori disebutkan bahwa semakin lama masa kerja seseorang maka semakin berpengaruh terhadap tingkat ambang dengarnya. Hasil dari penelitian ini tidak sesuai dengan teori, dikarenakan pada kelompok masa kerja $<5$ tahun banyak yang berusia muda yaitu $\leq 30$ tahun sehingga kemungkinan gangguan pendengaran diakibatkan oleh aktifitas lain diluar pekerjaannya. Selain itu untuk kelompok terpapar hal ini bisa dikarenakan kebiasaan pekerja yang jarang menggunakan APT saat bekerja karena beberapa pekerja baru belum pernah mendapat pelatihan mengenai kebisingan dan APD sehingga berpengaruh terhadap kenaikan ambang dengarnya.

Berdasarkan penelitian Kusumawati (2012), menunjukkan bahwa tidak ada hubungan antara masa kerja dengan gangguan pendengaran, dalam penelitian tersebut menyebutkan bahwa dari 110 pekerja terdapat 15 orang $(31,2 \%)$ mengalami gangguan pendengaran dengan masa kerja kurang dari 5 tahun.

\section{Penggunaan Alat Pelindung Telinga (APT)}

Dalam penggunaan APT, sebagian besar pekerja pada kelompok terpapar memiliki kebiasaan kadang-kadang dalam penggunaan APT dan pada kelompok tidak terpapar semua responden tidak menggunakan APT karena lingkungan kerja yang tidak terpapar bising. Dilihat dari hubungan antara penggunaan APT dengan kejadian gangguan pendengaran pada kelompok terpapar didapatkan hasil bahwa tidak ada hubungan antara kebiasaan pekerja dalam penggunaan APT dengan gangguan pendengaran pada telinga kiri dan kanan.

Menurut Soeripto (2008), cara terbaik untuk perlindungan pendengaran ialah dengan pengendalian teknis dimana pengendalian bising dilakukan pada sumber suara, tetapi pemakaian APD bisa menjadi cara lain yang dapat dilakukan. Alat pelindung seperti sumbat telinga (Ear Plug) dapat menurunkan intensitas kebisingan sebesar $25 \mathrm{~dB}-30 \mathrm{~dB}$ yang dapat digunakan pada area yang memiliki intensitas bising $<100 \mathrm{~dB}$.

Hasil dari penelitian ini tidak sesuai dengan teori. Hal ini mungkin terjadi karena beberapa pekerja yang sebagian besar kadangkadang menggunakan APT masih memiliki nilai ambang dengar yang baik. Setiap pekerja di PT.INKA yang berkerja di area bising telah mendapat alat sumbat telinga (ear plug) dan apabila ear plug tersebut sudah tidak layak pakai atau rusak bisa langsung dilakukan penggantian oleh pihak kantor.

Dari hasil observasi, peneliti menemukan beberapa pekerja yang kadang-kadang masih tidak menggunakan APT atau beberapa pekerja yang memakai APT hanya pada salah satu telinganya saja dikarenakan keperluan komunikasi dan beberapa merasa tidak nyaman saat menggunakan APT dalam jangka waktu lama. Dan bila pekerja tidak menggunakan ear plug tidak ada sanksi yang dikenakan untuk para pekerja, hanya berupa peringatan secara lisan yang disampaikan oleh supervisor.

Menurut program konservasi pendengaran. Pemilihan, penggunaan, perawatan dan penggantian Alat Pelindung Diri (APD) perlu diperhatikan. Tersedianya APD akan berguna untuk mereduksi tingkat kebisingan dilingkungan kerja. Penggunaan APD juga dapat melindungi saluran telinga dari ilfiltrasi beberapa bahan kerja yang berbahaya. Selain itu pengawasan dalam penggunaan APD yaitu cara pemakaian APD yang tidak sesuai prosedur dapat beresiko terjadinya gangguan pendengaran pada pekerja (Kusumawati, 2012).

\section{Gangguan Pendengaran}

Status pendengaran berdasarkan kelompok terpapar dan tidak terpapar, dimana untuk kelompok terpapar terdapat 4 responden $(26,7 \%)$ mengalami gangguan pendengaran dari jumlah 15 responden dan dari kelompok tidak terpapar terdapat 7 responden $(46,7 \%)$ mengalami gangguan pendengaran dari jumlah 15 responden. Gangguan pendengaran yang lebih banyak terjadi pada kelompok tidak terpapar dikarenakan kebiasaan pekerja diluar area kerja yaitu sering mendengarkan musik dan penggunaan alat komunikasi handphone dalam waktu yang agak lama. 
Rakhmanisa, et al. Hubungan Antara Intensitas Kebisingan dan Karakteristik Individu Dengan Gangguan Pendengaran Pada Pekerja di Madiun
JPH RECODE Maret 2018; 1 (2) : 144-154 http://e-journal.unair.ac.id/JPHRECODE
Hal yang dapat dilakukan untuk menanggulangi masalah gangguan pendengaran ini antara lain mengurangi paparan kebingan dari berbagai sumber baik di area kerja maupun diluar area kerja, apabila gangguan pendengaran masuk dalam kategori sedang dan berat maka dapat dilakukan rehabilitasi berupa pemakaian alat bantu dengar untuk memudahkan dalam berkomunikasi.

\section{Intensitas Kebisingan dan Gangguan Pendengaran \\ Dari hasil perhitungaan SPSS} menggunakan uji korelasi pearson, spearman, dan chi-square didapatkan hasil bahwa tidak ada hubungan antara intensitas kebisingan dengan gangguan pendengaran pada pekerja di PT.INKA Madiun. Artinya intensitas kebisingan yang tinggi tidak berkaitan dengan kejadian gangguan pendengaran yang dialami oleh pekerja, dikarenakan pada kelompok terpapar yang bekerja dengan intensitas kebisingan yang lebih tinggi memiliki kejadian gangguan pendengaran yang lebih sedikit $(26,7 \%)$ dibandingkan dengan kelompok yang tidak terpapar $(46,7 \%)$.

Penelitian Jayanti (2015) mengenai hubungan intensitas kebisingan dengan nilai ambang dengar di PT.X menunjukkan bahwa adanya hubungan antara kebisingan dengan nilai ambang dengar telinga kanan dan kiri pada tenaga kerja di lantai 3 PT.X. Dimana terdapat 24 responden $(66,7 \%)$ yang mengalami gangguan pendengaran dari jumlah 36 responden pada kelompok terpapar.

Berdasarkan Penelitian Manoppo (2013) mengenai hubungan antara kebisingan dan fungsi pendengaran pada petugas PT.Gapura Angkasa di Bandar Udara Sam Ratulangi Manado mennunjukkan bahwa tidak ada hubungan antara gangguan pendengaran dengan intensitas bising. Dari hasil penelitian tersebut dapat diketahui bahwa intensitas kebisingan bukanlah satu-satunya faktor yang dapat mengyebabkan gangguan pendengaran.

Penelitian Darmawan (2013) mengenai nilai ambang dengar yang dilakukan di PT. Bangun Sarana Baja menunjukkan bahwa dari 34 responden yang terpapar bising terdapat 19 responden $(55,9 \%)$ yang mengalami gangguan pendengaran.

Berdasarkan penelitian Kusumawati (2012) mengenai hubungan tingkat kebisingan dengan gangguan pendengaran di PT. X, dimana PT. X bergerak di bidang perakitan mesin cuci dan AC yang dalam proses produksinya memiliki beberapa jenis pekerjaan yang hampir sama dengan penelitian ini menunjukkan hubungan yang tidak bermakna antara pajanan kebisingan dengan gangguan pendengaran. Penelitian tersebut menggunakan studi cross sectional dengan jumlah responden kasus sebanyak 33 reponden dan 77 responden kontrol. Dari pengujian audiometrik diketahui bahwa sebanyak 8 pekerja $(24,2 \%)$ mengalami gangguan pendengaran sementara dari kelompok kontrol yang mengalami gangguan pendengaran berjumlah 25 pekerja $(32,5 \%)$.

Hasil penelitian ini memiliki kesesuaian hasil dengan penelitian Kusumawati (2012) walaupun jumlah responden yang diambil dalam penelitian tersebut tidak sama. Dimana pada penelitian ini jumlah kelompok terpapar yang mengalami gangguan pendengaran sebanyak $26,7 \%$ dan pada penelitian Indah sebanyak $24,2 \%$.

Sedikitnya jumlah pekerja yang mengalami gangguan pendengaran pada kelompok terpapar dibandingkan kelompok tidak terpapar ini akibat adanya kelemahan penelitian yaitu saat pemeriksaan audiometri, pekerja pada kelompok terpapar tidak memiliki waktu untuk beristirahat sebentar agar tidak terjadi kemungkinan untuk mendengar kebisingan saat pengukuran, akibat pajanan bising dengan intensitas tinggi yang mengakibatkan responden tidak dengan benar memberikan respon saat mendengar suara pada tes audiometri sehingga data yang didapat menjadi tidak akurat. Keterbatasan penelitian dalam hal tes audiometri ini dikarenakan jadwal dan jam kerja yang padat sehingga pekerja tidak boleh meninggalkan pekerjaan terlalu lama, tes audiometripun dilakukan bergantian agar tidak banyak membuang waktu kerja pekerja. Sedangkan pada kelompok tidak terpapar mendapat paparan bising diluar area kerjanya yaitu kebiasaan mendengarkan musik melalui headset dan berkomunikasi telepon dalam waktu yang lama.

Berdasarkan Penelitian Pandu (2012) kebiasaan pekerja mendengarkan musik dengan headset dapat mempengarhi pendengaran pekerja sehingga menimbulkan gangguan komunikasi. Terlalu sering menggunakan atau terlalu memaksa pemakaian headset akan 
Rakhmanisa, et al. Hubungan Antara Intensitas Kebisingan dan Karakteristik Individu Dengan Gangguan Pendengaran Pada Pekerja di Madiun

menyebabkan kerusakan gangguan pendengaran atau penurunan fungsi pendengaran, semua itu terjadi akibat kelelahan cochlea yang berfungsi dalam proses pendengaran. Kelelahan cochlea yang terjadi terus-menerus dan tidak segera ditangani dapat menyebabkan gangguan pendengaran menetap dan dapat menimbulkan gangguan komunikasi. Salah satu cara untuk mengurangi gangguan pendengaran adalah dengan mengurangi volume suara dan waktu untuk mendengarkan musik melalui headset.

\section{KESIMPULAN}

Intensitas kebisingan pada area kerja welding 1 melebihi NAB (94,8 dBA) sedangkan intensitas kebisingan untuk ruang kantor sebagai kelompok pembanding sebesar 63,2 dBA.

Karakteristik pekerja berdasarkan usia, sebagian besar pekerja berusia $\geq 30$ tahun dengan masa kerja $<5$ tahun dan untuk penggunaan APT pada kelompok yang terpapar bising, sebagian besar pekerja kadang-kadang memakai APT. Berdasarkan hasil uji statistik dapat diketahui bahwa tidak ada hubungan antara karakteristik individu (usia, masa kerja dan penggunaan APT) dengan gangguan pendengaran pada pekerja di PT.INKA.

Gangguan pendengaran yang terjadi pada pekerja di PT.INKA untuk kelompok terpapar sebanyak 4 responden $(26,7 \%)$ dan untuk kelompok tidak terpapar sebanyak 7 responden $(46,7 \%)$. Hal ini dikarenakan tidak adanya waktu istirahat yang cukup sebelum dilakukan tes audiometri pada kelompok terpapar dan kebiasaan diluar pekerjaan pada pekerja kelompok tidak terpapar yaitu sering mendengarkan musik melalui headset .

Berdasarkan analisis data dan hasil uji analisis statistik menunjukkan bahwa tidak ada hubungan antara intensitas kebisingan dengan gangguan pendengaran yang terjadi pada pekerja di PT.INKA. Dengan hasil uji Chi-Square diperoleh nilai $\mathrm{p}$ (Asymp. Sig) adalah 0,449 Karena nilai $p>\alpha(0,05)$. Maka interpretasinya adalah bahwa tidak ada hubungan antara intensitas kebisingan dengan gangguan pendengaran yang terjadi pada pekerja. Artinya bahwa kebisingan tinggi pada area kerja bukan merupakan patokan terhadap terjadinya gangguan pendengaran pada pekerja, tetapi dapat juga dipengaruhi oleh faktor lain seperti kebiasaan lain yang dilakukan diluar area kerja.
JPH RECODE Maret 2018; 1 (2) : 144-154 http://e-journal.unair.ac.id/JPHRECODE

\section{SARAN}

Sebaiknya dilakukan pelatihan untuk meningkatkan pengetahuan terkait kebisingan dan dampaknya bagi kesehatan dan pentingnya penggunaan Alat Pelindung Telinga (APT) pada pekerja yang terpapar bising. Melakukan pengawasan lebih ketat terhadap para pekerja di area bising yang kadang-kadang dan tidak memakai APT dengan menentukan banyaknya peringatan dan adanya sanksi. Untuk pekerja pada kelompok tidak terpapar (kantor) sebaiknya mengurangi volume dan waktu saat mendengarkan musik melalui headset dan berkomunikasi telepon karena hal tersebut dapat mempengaruhi kenaikan nilai ambang dengar dan apabila berlangsung terus menerus maka keadaan gangguan pendengaran akan lebih berat. Mengurangi intensitas bising pada area kerja dengan mengisolir pekerjaan dengan kebisingan tinggi di tempat yang terpisah atau agak jauh dengan pekerjaan yang tidak terlalu bising.

\section{DAFTAR PUSTAKA}

Albustomi, Y. dan Denny. A. W. 2017. Perbedaan Tekanan Darah Sistole Dan Diastole Sebelum Dan Setelah Kerja Pada Pekerja Yang Terpapar Bising Di PT X. Journal of Public Health Research and Community Health Development, 1(1), pp. 27-37.

Ali, I. 2006. Mengatasi Gangguan pada Telinga dengan Tanaman Obat. Jakarta: Agromedia Pustaka.

Darmanto, R. 1999. Keselamatan Kerja dan Pencegahan Kecelakaan di Perusahaan. Semarang: Karya Pustaka.

Darmawan, V. 2013. Hubungan Karakteristik Individu dengan Nilai Ambang Dengar Pada Tenaga Kerja di PT. Bangun Sarana Baja Gresik. Skripsi, Universitas Airlangga, Surabaya.

Grandjean, E. 1993. Fitting the Task to the Man. 4th ed. London: Taylor and Francis Inc.

Jayanti, P. C. 2015. Hubungan Intensitas Kebisingan dengan Nilai Ambang Dengar Tenaga Kerja Terpapar Bising (Studi Kasus di Lantai 3 PT. X). Skripis, Universitas Airlangga, Surabaya.

Kusumawati, I. 2012. Hubungan Tingkat Kebisingan di Lingkungan Kerja Dengan Kejadian Gangguan Pendengaran Pada Pekerja di PT. X. Skripis, Universitas 
Airlangga, Surabaya.

Manoppo, F. 2013. Hubungan antara Kebisingan dan Fungsi Pendengaran Pada Petugas PT.Gapura Angkasa di Bandar Udara Sam Ratulangi Manado. Skripsi, Universitas Sam Ratulangi Manado, Manado.

Menteri Tenaga Kerja dan Transmigrasi. 2011. Peraturan Menteri Tenaga Kerja dan Transmigrasi Nomor 13/MEN/X/2011 Tentang Nilai Ambang Batas Faktor Fisika dan Kimia di Tempat Kerja.

Pandu, R. 2012. Beberapa Faktor Penyebab Gangguan Komunikasi di PT. Berca Schindler Lifts Surabaya. Skripis, Universitas Airlangga, Surabaya.

Pratama, T. 2010. Analisis Hubungan Umur dan Lama Pemajanan dengan Daya Dengar Berdasarkan Hasil Pemeriksaan Audiometri Tenaga Kerja di Unit Produksi Central Processing Area Job P-PEJ Tuban Jawa Timur. Skripsi, Universitas Sebelas Maret Surakarta.

Pulat, M. B. 1992. Fundamentals of Industrial Ergonomic. AT \& T Network System: Oklahoma.

Sihar, T. B. T. 2005. Kebisingan di Tempat Kerja (Occupational Noise). Yogyakarta, Andi.

Siswanto, A. 1991. Ergonomi. Surabaya: Balai Hiperkes dan Keselamatan Kerja.

Soeripto, M. 2008. Higiene Industri. Jakarta: Balai Penerbit FKUI.

Standard, J. 1979. Industrial Noise. Fundamental of Industrial Hygiene. Itasca : National Safety Council. 